\author{
Agnieszka Marek \\ John Paul II Catholic University of Lublin, Faculty of Social Sciences \\ Institute of Economics and Management \\ e-mail: agnieszka.marek@kul.pl
}

\title{
Leadership in Catholic Social Teaching
}

\begin{abstract}
The material subject of Catholic social science is man and his actions taken in the fields of politics, the economy and society. According to its rules each person should be engaged in building the world through the realization of his or her vocation. One kind of vocation might be leading people by acting in accordance with the Gospel and teachings of the Church. The most important values for the leader in this case would be: respect for human dignity and human rights, freedom, justice, the subsidiarity principle and cooperation due to creating the common good. The listed rules are realized by servant leadership, the idea functioning in the field of management that derives its origins from Christ's speech: whosoever will be chief among you, let him be your servant (Mt 20:27).
\end{abstract}

Keywords: Catholic social science, servant leadership, values

JEL Classification: M54, Z12

\section{Introduction}

It may seem that Catholic social teaching does not address the subject of leadership but it says a lot about human work, employers and employees as well as about man's vocation. Those issues have a lot in common with leadership because the role of a leader, if realised in agreement with God's Word, can be a way of answering His calling. Catholic social teaching can be inspirational for people who are endowed with the talent to lead the others. If they seek God's will in their lives, choose the 
way that He had prepared for them, they participate in the act of creation and encourage others to do the same. It is so because they know that God has trusted them and has given them exceptional skills, at the same time expecting them to be more responsible for the managed organisation in accordance with the Biblical rule: "from everyone who has been given much, much will be demanded; and from the one who has been entrusted with much, much more will be asked' (Luke 12:48). The importance and topicality of the subjects of business and leadership in the light of the Church's teaching has been recently shown in the document released by Pontifical Council of Justice and Peace titled Vocation of the Business Leader: A Reflection. ${ }^{1}$

\section{The essence of leadership}

'Leadership' as well as 'leader' are ambiguous terms with almost as many definitions as people who discuss the subject. Some academics believe that leadership and management are exactly the same concepts, while others enumerate differences between those two with great attention to detail. There is also a group of both theorists and practitioners who regard leadership as one of management's functions closely related to motivating people and facilitating their efforts in achieving stated goals. In brief, it might be assumed that management concerns 'hard', mainly measurable aspects of organisational functioning, while leadership refers to 'soft' issues and competencies including social, cultural or even emotional aspects, and often depends on the personal features of the leader. ${ }^{2}$ For efficient organisational performance both leadership and management should be joined in optimal proportions so one cannot overrate or depreciate any of them.

For the purpose of this paper leadership will be understood as an inspiration for other people which enables them to perceive their hidden potential. ${ }^{3}$ Haven taken this assumption into account, one might say that the act of accepting a leader originates not in people's minds, but in their hearts, and it flourishes as a consequence of mutual interactions and relations, and not because of the progressively increasing number of tasks and orders. Real leadership guarantees that employees will do much more than they have to because they will be able to break down the barriers of their own interests. ${ }^{4}$

The foundation of efficacious leadership is the ability to encourage people to achieve organisational aims, of which the first is the mission. Good leaders know how to create and present the main goal of the organisation in order to make it understandable, achievable and attractive to the employees. They also set priorities

\footnotetext{
${ }^{1}$ Pontifical Council of Justice and Peace, Vocation of the Business Leader: A Reflection, Vatican 2012; http://www.pcgp.it/dati/2012-05/04-999999/ Vocation\%20ENG2.pdf (accessed July 29, 2014).

${ }^{2}$ Cf. A.K. Koźmiński, D. Jemielniak, Zarządzanie od podstaw, Wolters Kluwer business, Warsaw 2011, p. 23.

${ }^{3}$ Cf. S. Covey, Przywództwo jest wyborem, "Personel i Zarządzanie" 2003, No. 7, p. 56; A. StankiewiczMróz, Przywództwo wyzwaniem dla wspótczesnego kierownika [in:] Zarządzanie zasobami ludzkimi dla menedżerów średniego szczebla, ed. E. Jędrych, Wolters Kluwer Polska, Cracow 2007, p. 84.

${ }^{4}$ Cf. A. Wajda, Osobowość przywódcy, style przewodzenia [in:] Wymiary przywództwa w organizacji XXI wieku, ed. W. Bańka, Wydawnictwo naukowe NOVUM, Plock 2004, p. 115.
} 
and sequence targets, decide about standards and require their implementation. The most important task for them, however, seems to be inspiring people to use their potential to find the best way of achieving common goals. There are four main activities a leader might take to encourage people to work on the targets: ${ }^{5}$

(1) supporting employees, which is aimed at building their self-esteem;

(2) facilitating interactions, which means encouraging people to build satisfactory relationships within the organization;

(3) putting emphasis on goals and sharing enthusiasm within the staff;

(4) helping provide necessary assets and conditions for the realisation of tasks.

Leadership is strongly connected to implementing changes and innovative solutions. That is why one of the vital parts of the leader's role is being an innovator who starts new projects and feels responsible for their realisation. Catholic leaders see those projects as a part of a bigger goal and not only as a tool or means for making a profit. For them each business activity, as a community of people pursuing a common goal, has value in itself, much broader than only a financial profit. ${ }^{6}$ The key to successful inspiration of changes and implementation of innovations is, first of all, people, both individually and in teams. The following are important factors: culture, social issues and communication. In other words, effective change within an organisation may be introduced only in a proper work environment in agreement with the staff who understand the sense of the change and see the positive outcome of the improvements. ${ }^{7}$ That is why the leaders have to present necessary changes to their employees in a just way, with their positive and negative consequences, to enable them to understand how they will result in achieving organisational goals and how they will influence people's work and their relationships.

\section{Leadership as a vocation}

There is no universal method of guiding people but there seems to be one assumption which distinguishes leaders with motivation from the ones with a vocation. The difference between them is that the first ones think that they are the owners of possessed money, the company, relationships with people and the social or material status, while the others know that they owe everything to $\operatorname{God}^{8}$ for the reason that $\mathrm{He}$ is the Creator of the world and everything depends on His will. God is in the centre of Catholic leaders' life, work, decisions and actions, because they are aware that the work is completed not only for earthly progress but also for the development

\footnotetext{
${ }^{5}$ Cf. A. Stankiewicz-Mróz, op. cit., p. 84.

${ }^{6} \mathrm{Cf}$. Address of Cardinal Tarcisio Bertone Secretary of State for the Opening of the Executive Summit on Ethics for the Business World, 16 June 2011, http://www.vatican.va/roman_curia/secretariat_state /card-bertone/2011/documents/rc_seg-st_20110616_business-ethics_en.html (accessed July 29, 2014).

${ }^{7}$ Cf. A. Drzewiecki, D. Chełmiński, E. Kubica, Dobre przywództwo. Najlepsze praktyki polskich liderów biznesu, Oficyna a Wolters Kluwer business, Warsaw 2011, p. 37.

${ }^{8}$ Cf. K. Blanchard, Przywództwo wyższego stopnia, Wydawnictwo Naukowe PWN, Warsaw 2007, pp. 217-218.
} 
of God's Kingdom, therefore they combine performing duties with prayer. ${ }^{9}$ The consequences of thinking in that way is perceiving all managed goods as a kind of a loan, as Biblical talents which were entrusted to His servants (Mt 25:14) and which should be given back with interest (Mt 25:27).

The interest from work in this perspective is not only, and not even mainly, material. First of all, it means that through their work leaders as well as their employees get closer to their Creator and cooperate with Him in improving the world, as they 'have a special role to play in the unfolding of creation - they not only provide goods and services and constantly improve them through innovating and harnessing science and technology, but they also help to shape organisations which will extend this work into the future. ${ }^{10}$ Secondly, the aim of human work is the development of man himself. While conducting his duties, man transforms not only his environment but he also, as the conscious subject of work, achieves fulfilment as a human being and aspires to personal excellence. The effects of his deliberate actions remain in him, shape him and enable him to develop as a person. ${ }^{11}$

People who see their ability to lead others as a vocation should accept the principles they received from God to stimulate the integral development of those who benefit from the business as employees, customers and the local society. ${ }^{12}$ According to the literature on Catholic social teaching, values essential for the employer are: respect for employees with their personal dignity and vested rights; primacy of work in relation to capital; the subsidiarity principle; and the common good. What is more, work should be treated as a way which leads to salvation and is participation in the act of creating the world. In the following part of the paper there will be an explanation of how all those values influence the style of leadership.

\section{Man as a subject of work in employee-oriented leadership}

First of all, Catholic leadership requires treating each employee not as an object of work but as its subject, ${ }^{13}$ which is connected directly with protection of human's rights, respect of one's dignity and primacy of employee's well-being in relation to capital. With development of economy one can notice the change in decisive factors of production. Previously it was the land and capital, which should be understood as all of the instruments of production. Today the most important factor in business is the man himself, with his knowledge, competencies, his will to work and the ability to perceive the needs of other people and to satisfy them. ${ }^{14}$ That is why people should be treated with respect for themselves, their dignity and their rights.

\footnotetext{
${ }^{9}$ Cf. John Paul II, Encyclical letter Laborem exercens, No. 27, TUM, Wroclaw 1995, pp. 98-99.

${ }^{10}$ Pontifical Council of Justice and Peace, Vocation of the Business Leader, No. 7.

${ }^{11}$ Cf. John Paul II, Laborem exercens, No. 9, p. 33; S. Fel, Spoleczno-etyczny wymiar pracy ludzkiej [in:] Katolicka Nauka Społeczna. Podstawowe zagadnienia z życia gospodarczego, eds. J. Kupny, S. Fel, Księgarnia św. Jacka, Katowice 2003, p. 29.

${ }^{12}$ Cf. Pontifical Council of Justice and Peace, Vocation of the Business Leader, No. 67.

${ }^{13}$ Cf. John Paul II, Laborem exercens, No. 5-6, pp. 16-23.

${ }^{14}$ Cf. Idem, Encyclical letter Centessimus annus, No. 32, TUM, Wroclaw 2000, p. 66.
} 
A fundamental human right is the right to life and all other rights are justified because of that one. Human life is inseparably linked with personal dignity and both are incomparable to other goods and values. That is why an employer should create working conditions in which human life will not be endangered and 'man himself should not experience a lowering of his own dignity.' ${ }^{15}$ According to Laborem exercens 'the human rights that flow from work are part of the broader context of those fundamental rights of the person. ${ }^{16}$ The basic rights of man with respect to work are: the right to work; the right to a just salary; the right to own property; the right to participation in management, ownership and profit; the right to a decent life standard; the right to social security and benefits; the right of association; and the right to strike. ${ }^{17}$ John Paul II also includes the right to rest in three aspects: rest at least on every Sunday; a longer leave during holidays; a pension and insurance for old age or in case of accidents at work. ${ }^{18}$ Rest is as important as the work itself because, due to leisure time, a person has a chance to cultivate familial, social, cultural and religious life. Moreover, it enables people to develop talents and potential, which cannot be improved through their professional work. ${ }^{19}$

One of the most important rules which should be practiced in leadership consistent with Catholic social teaching is the primacy of work in relation to capital. Among all creatures on the Earth only man is made in the image and likeness of God Himself (Cf. Gen 1:26), and his task, which can be fulfilled by work, is to subdue the Earth (Cf. Gen 1:28). In addition to that, it must be said that means of work cannot exist without man, so any kind of capital is a result of human ideas and actions taken. That is why the importance of man is incomparable with any means of work, including capital, as well as the newest technological inventions. ${ }^{20}$

It does not mean the Church does not recognise the role of profit as an indicator of an enterprise's condition. Profitability indeed shows that a company works well but it cannot be the only form of measurement and the exclusive purpose of its existence. A firm 'is to be found in its very existence as a community of people who in various ways endeavour to satisfy their basic needs, and who form a particular group at the service of the whole of society. ${ }^{21}$ That is why, except for profitability, other human and moral factors also play a very important role as regulators of social life. The profit is a reward for the company for the customer care and appropriate fulfilling of the customers' needs, as well as for the creation of working conditions in which employees are motivated and recognised by their supervisors. ${ }^{22}$

\footnotetext{
${ }^{15}$ Idem, Laborem exercens, No. 9, p. 33.

${ }^{16}$ Cf. Ibidem, No. 16, p. 58.

${ }^{17}$ Cf. S. Fel, op. cit., pp. 37-45.

${ }^{18}$ Cf. Laborem exercens, No. 19, p. 72.

${ }^{19}$ Cf. Sobór Watykański II, Konstytucja duszpasterska o Kościele w świecie współczesnym Gaudium et spes, No. 67, Pallotinum, Poznan 2012, p. 583.

${ }^{20}$ Cf. John Paul II, Laborem exercens, No. 12, pp. 41-44.

${ }^{21}$ John Paul II, Centessimus annus, No. 35, p. 72.

${ }^{22}$ Cf. K. Blanchard, op. cit., pp. 4-5; V.M.L. Storsletten, O.D. Jakobsen, Development of Leadership Theory in the Perspective of Kierkegaard's Philosophy, "Journal of Business Ethics" 2014, No. 128, p. 5 .
} 
The way of practical realisation of both primacy of work in relation to capital and subjectivity of human being in the process of work might be employee-oriented leadership. In an organisation oriented towards employees the basic value for building organisational identity is the employee's subjectivity. It means that people know that a supervisor will not only listen to them and their ideas but also put the best innovations into organisational practices, and that employees will be recognised for their participation in the success. What is more, in such companies employees are provided with information about the organisation's current situation and plans for the future. ${ }^{23}$

The most difficult task for leaders is to find the best ways for enabling employees to unleash their potential for the good of their company. They might do that by using a variety of motivational factors which may encourage people to engage more fully in achieving organisational aims. ${ }^{24}$ Vital for the leader in this process is showing how important the role is of each member of the organisation; how taken decisions and actions influence the company's functioning, its speed of reaction, efficiency and goal accomplishment. ${ }^{25}$ To show people that they are in the centre of the organisation and that they are the most important for its success, the leaders have to be authentic which means that their words must be in agreement with their actions, as statements without employees' recognition and affirmation mean nothing. That is why genuine leaders must implement organisational key values, especially people-oriented ones, into practice and build a high performance work environment. ${ }^{26}$

It is often said by management practitioners that putting people first means also using language that does not show any disrespect or disdain towards the organisation's members. They propose referring to them as 'associates' or 'team members' rather than 'employee' or 'worker.' It is also unacceptable to use the term 'human resources' as it is disrespectful and relegates people to the same status as machines or other assets. ${ }^{27}$ Similar problems are created when using the term 'human capital,' because according to human capital management theory people are regarded as one of several different kinds of capital which require taking investments that should give a decent return on spent money. ${ }^{28}$ The value of a person in this concept is not a value per se but is measurable and depends on different indicators, which means that people are valuable as long as their talents and qualifications are needed within the organisation and help in building its competitive advantage.

\footnotetext{
${ }^{23}$ Cf. M. Świątkowski, Zarzadzanie przez kulturę organizacji [in:] Wymiary przywództwa w organizacji XXI wieku, ed. W. Bańka, Wydawnictwo naukowe NOVUM, Plock 2004, p. 324.

${ }^{24}$ Cf. Z. Sekuła, Motywowanie do pracy. Teorie i instrumenty, PWE, Warsaw 2008, p. 46; M. Armstrong, Zarzadzanie ludźmi. Praktyczny podręcznik dla menedżerów liniowych, Dom Wydawniczy Rebis, Poznan 2007, p. 43.

${ }^{25}$ Cf. J. Hoover, A. Valenti, Unleashing Leadership, Career Press, Franklin Lakes 2005, p. 56.

${ }^{26}$ Cf. J. Pffefer, The Human Equation: Building Profits by Putting People First, Harvard Business School Press, Boston 1998, pp. 294-297.

${ }^{27}$ Cf. Ibidem, p. 294.

${ }^{28}$ Cf. A. Marek, Capital, Resource or People? Contemporary Trends in Personnel Management, „Annales. Ethics in Economic Life" 2014, Vol. 17, No. 2, p. 78.
} 


\section{Participation in management as creation of common good}

One of the fundamental values in Catholic social teaching is the common good. That is why Catholic leaders should not strive to achieve their own benefits but, first and foremost, should seek to ensure the common good of all members of the organisation. They ought to be able to unite the staff in pursuing the mission of the company and through that to participate in building the prosperity of their employees, their families, customers, the local community and, as a result, in the development of the world. For the purpose of aiming at achieving the common good 'we urgently need business leaders for whom profits is not the exclusive goal. More and more, we need business leaders with a social conscience, leaders whose innovation, creativity and efficiency are driven by more than profit, leaders who see their work as part of a new social contract with the public and with civil society. ${ }^{29}$ That is why, as stated before, an enterprise needs to be perceived not as an organisation which pursues only material profit, but as a community of people who work together at the service of the society. Creating a true human community within an organisation requires understanding, good will and appreciation between leaders and employees. ${ }^{30}$ Members of that community should work 'together for the advancement of their mutual interests in accordance with the principles of justice and Christian teaching. ${ }^{\text {'}}{ }^{1}$ It is mutually profitable, as in a company people fulfil the needs of others using their own gifts, talents, skills and energy, and in return they receive the support in their professional and individual development. ${ }^{32}$

Achieving a common goal requires a change in the way of thinking. One has to switch from perceiving the world as ' $\mathrm{I}$ ' - an individual, to 'we' - a community of people. People are called to live in a 'we' relationship, in which they can give themselves to others and through that selfless gift they might realise their humanity. ${ }^{33}$ As written in Centesimus annus: it is human 'disciplined work in close collaboration with others that makes possible the creation of ever more extensive working communities which can be relied upon to transform man's natural and human environments. Important virtues are involved in this process, such as diligence, industriousness, prudence in undertaking reasonable risks, reliability and fidelity in interpersonal relationships, as well as courage in carrying out decisions which are difficult and painful but necessary, both for the overall working of a business and in meeting possible set-backs. ${ }^{34}$

Building a genuine community requires people's engagement which, in management practices, might be realised through employees' participation, understood as the set of means that employees are entitled to use in order to engage in taking

\footnotetext{
${ }^{29}$ Address of Cardinal Tarcisio Bertone..., op. cit.

${ }^{30}$ Cf. John XXIII, Encyclical letter Mater et Magistra, No. 91, TUM, Wroclaw 1997, p. 38; J. Kupny, Przedsiębiorstwo wspólnotą osób pracujących [in:] Katolicka Nauka Społeczna. Podstawowe zagadnienia z życia gospodarczego, eds. J. Kupny, S. Fel, Księgarnia św. Jacka, Katowice 2003, pp. 95-97.

${ }^{31}$ John XXIII, Mater et Magistra, No. 141, p. 59.

${ }^{32}$ Pontifical Council of Justice and Peace, Vocation of the Business Leader, No. 40.

${ }^{33}$ Cf. M. Baczewska-Ciupak, Przywództwo organizacyjne w kontekście aksjologicznych i moralnych wyzwań przyszłości, Wydawnictwo UMCS, Lublin 2013, pp. 206-207.

${ }^{34}$ John Paul II, Centessimus annus, No. 32, pp. 65-66.
} 
decisions within the organisation. ${ }^{35}$ However, in the theory of management there is also a concept of full participation, which means a way of leading an organisation based on the assumption that each and every employee has an inherent right of participation, and this involvement results in a long-term, constant and positive influence on achieving organisational aims as well as on employees. What is more, it also causes a higher congruence of workers' goals with organisational ones. ${ }^{36}$ Each person has the right to participate in management within the organisation that he or she works for in many ways, but in general the participation can be divided into direct and indirect.

Indirectly, a person may participate in management by different forms of representation of workers who are chosen in order to advise, consult or negotiate some projects or particular decisions as well as suggest needed changes in the enterprise, or control some aspects of actions taken within the organisation. ${ }^{37}$ The workers also have the right of association and they can influence working conditions such as wages, working hours and others through trade unions which guard and defend employees' rights. $^{38}$

A direct form of participation in management is connected to task delegation and cooperation for the common good of the organisation. Good leaders know their employees and are able to decide which person has the proper qualifications to execute a task that is a part of a bigger project, and which employees should cooperate as a team to realise the project. A leader is responsible for commissioning the task to the person in the lowest competent post within the organisation, reflecting the subsidiarity principle. In a broader sense this principle says that 'it is gravely wrong to take from individuals what they can accomplish by their own initiative and industry and give it to the community, so also it is an injustice and at the same time a grave evil and disturbance of right order to assign to a greater and higher association what lesser and subordinate organizations can do. ${ }^{39}$ At the level of an individual it has to be said that God entrusted man with different tasks and made each person able to have the power according to the capacities of their own nature. ${ }^{40}$ As an image of God each person is able to use his or her intelligence and freedom in the best possible way, ${ }^{41}$ which is why leaders should be able to inspire people to find this way and use it for the common good of the organisation.

Delegating tasks helps employees to contribute in an organisation's life by attending to their own individual tasks to the best of their abilities. Due to respecting 'the principle of subsidiarity, employees at a lower level who are trusted, trained, experienced, know precisely the extent of their responsibilities, and are free to make

\footnotetext{
${ }^{35}$ Cf. A. Cierniak-Emerych, Pojęcie partycypacji pracowniczej na tle literatury przedmiotu oraz ustawodawstwa wspólnotowego [in:] Perspektywy rozwoju partycypacji pracowniczej $w$ Polsce $w$ warunkach Unii Europejskiej, ed. S. Rudolf, Lodz University Press, Lodz 2007, p. 34.

${ }^{36}$ Cf. R. Stocki, P. Prokopowicz, G. Żmuda, Petna partycypacja w zarządzaniu. Tajemnica sukcesu największych eksperymentów menadżerskich świata, Wolters Kluwer Polska, Cracow 2008, p. 314.

${ }^{37}$ Cf. Z. Sekuła, op. cit., p. 46.

${ }^{38}$ John Paul II, Laborem exercens, No. 20, pp. 72-73.

${ }^{39}$ Pius XI, Quadragesimo anno, No. 79, Jedność, Kielce 1946, p. 58.

${ }^{40}$ Catechism of the Catholic Church, No. 1884, Pallotinum, Poznan 1994, p. 438.

${ }^{41}$ Pontifical Council of Justice and Peace, Vocation of the Business Leader, No. 47.
} 
decisions, can fully use their freedom and intelligence, and thus are enabled to develop as people; they are indeed "co-entrepreneurs". ${ }^{42}$ Direct participation in management facilitates employees' development, their initiative, creativity and a sense of responsibility shared among all members of an organisation. ${ }^{43}$

Although the leader inspires the company's members to realise a created vision and fixed strategy, each and every person takes part in forming the actual shape of the organisation. That is why the leaders should teach the employees that they are responsible for their company and they really participate in its success as every task is important for achieving the common goals. ${ }^{44}$ It is possible only in a situation when the leader delegates not only the task but also entitlements and responsibilities connected with the actions. Otherwise it would look like the manager wanted to dispose of the task and thought that the employee was unreliable and could not handle responsibility or use full powers that are needed to fulfil the duty. Letting people be independent and responsible for their decisions and actions is equal to accepting their freedom and enabling them to create a common good in their own way. At the same time people learn on the job and are able to invent newer, better and more effective ways of solving problems and implementing discovered solutions.

It has to be emphasised that the common good is not a simple sum of individual goods ${ }^{45}$ but it is 'linked to living in society. (...) It is a good that is sought not for its own sake, but for the people who belong to the social community and who can only really and effectively pursue their good within it. ${ }^{56}$ Each organisation is a society and all its members should cooperate in building this common good using their talents and knowledge. Acting in agreement with the teachings of the Church, the leader should encourage employees to sacrifice their individual goods for the common good of the organisation, but foremost he or she has to show that the common good is the primary aim also for him.

Leaders who respect people, their right to participation in management, who trust them and share responsibility with them, are able to coordinate cooperation in a way that enables a synergistic effect to be achieved. It means that the effect of people's teamwork is much greater than the sum of the individual effects of work of the same people. ${ }^{47}$ That outcome of cooperation is possible because of the favourable working conditions which are: concentration of resources; cooperation based on trust under a common leader; specialisation of work and sharing of work experience. ${ }^{48}$ The role of the leader in this process is creating a team containing the proper number of people with complementary qualifications, one that will be able to realise the stated goals. Thanks to cooperation people will perceive themselves as a part of community, they will not be oriented towards possessing material goods

\footnotetext{
${ }^{42}$ Ibidem, No. 50.

${ }^{43}$ Ibidem, No. 48.

${ }^{44}$ A. Marek, Zarządzanie przez kulturę organizacyjna jako sposób na rozwój potencjału pracowników [in:] Nowe tendencje w zarządzaniu, ed. M. Pawlak, Wydawnictwo KUL, Lublin 2010, p. 114.

${ }^{45}$ G. Campanini, Dobro wspólne a pomocniczość, "Społeczeństwo" 2003, Vol. 17, No. 3, p. 421.

${ }^{46}$ Benedict XVI, Encyclical letter Caritas in veritate, Wydawnictwo M, Cracow 2009, No. 7, p. 9.

${ }^{47}$ K. Kmiotek, T. Piecuch, Zachowania organizacyjne. Teoria i przykłady, Difin, Warsaw 2012, p. 102.

${ }^{48}$ E. Jędrych, Kierowanie zespołami pracowniczymi [in:] Zarządzanie zasobami ludzkimi dla menedżerów średniego szczebla, ed. E. Jędrych, Oficyna, Cracow 2007, p. 198.
} 
but to serving others and using their abilities for creating the common good. They will also easily share their knowledge and experience, as they will know that the team's success is also their success.

\section{Conclusions}

In the centre of leadership consistent with Catholic social teaching is man as image Deo who is able to change himself and his surroundings through the conscious act of work. People who are called to lead others have to respect the fundamental rights of workers and their dignity as well as implement a set of rules which are the basics of the Church's teachings. In management practice those values might be realised by an employee-oriented leadership and participation in management, which assume the subjectivity of the working people, cooperation for the common good and respecting of the subsidiarity principle through task delegation.

To sum up, being a good leader is not a matter of character features but a matter of choosing the proper set of values and methods of acting. According to the teaching of the Church business leaders should: 'see the challenges and opportunities in the world of work; judge them according to the social principles of the Church; and act as leaders who serve God. ${ }^{49}$

\section{References}

Address of Cardinal Tarcisio Bertone Secretary of State for the Opening of the Executive Summit on Ethics for the Business World, 16 June 2011; http://www.vatican.va/roman_curia/secretariat_state/card-bertone/2011/documents/rc_seg-st_20110616_bus iness-ethics_en.html.

Armstrong M., Zarządzanie ludźmi. Praktyczny podręcznik dla menedżerów liniowych, Dom Wydawniczy Rebis, Poznan 2007.

Baczewska-Ciupak M., Przywództwo organizacyjne w kontekście aksjologicznych i moralnych wyzwań przyszłości, Wydawnictwo UMCS, Lublin 2013.

Benedict XVI, Encyclical letter Caritas in veritate, Wydawnictwo M, Cracow 2009.

Blanchard K., Przywództwo wyższego stopnia, Wydawnictwo Naukowe PWN, Warsaw 2007.

Campanini G., Dobro wspólne a pomocniczość, “Społeczeństwo” 2003, Vol. 17, No. 3.

Catechism of the Catholic Church, Pallotinum, Poznan 1994.

Cierniak-Emerych A., Pojęcie partycypacji pracowniczej na tle literatury przedmiotu oraz ustawodawstwa wspólnotowego [in:] Perspektywy rozwoju partycypacji pracowniczej w Polsce w warunkach Unii Europejskiej, ed. S. Rudolf, Lodz University Press, Lodz 2007.

Covey S., Przywództwo jest wyborem, "Personel i Zarządzanie" 2003, No. 7.

\footnotetext{
${ }^{49}$ Pontifical Council of Justice and Peace, Vocation of the Business Leader, No. 87.
} 
Drzewiecki A., Chełmiński D., Kubica E., Dobre przywództwo. Najlepsze praktyki polskich liderów biznesu, Oficyna a Wolters Kluwer business, Warsaw 2011.

Fel S., Społeczno-etyczny wymiar pracy ludzkiej [in:] Katolicka Nauka Społeczna. Podstawowe zagadnienia z życia gospodarczego, eds. J. Kupny, S. Fel, Księgarnia św. Jacka, Katowice 2003.

Hoover J., A. Valenti, Unleashing Leadership, Career Press, Franklin Lakes 2005.

Jędrych E., Kierowanie zespołami pracowniczymi [in:] Zarzadzanie zasobami ludzkimi dla menedżerów średniego szczebla, ed. E. Jędrych, Oficyna, Cracow 2007.

John Paul II, Encyclical letter Centessimus annus, TUM, Wroclaw 2000.

John Paul II, Encyclical letter Laborem exercens, TUM, Wroclaw 1995.

John XXIII, Encyclical letter Mater et Magistra, TUM, Wroclaw 1997.

Katolicka Nauka Spoleczna. Podstawowe zagadnienia z życia gospodarczego, eds. J. Kupny, S. Fel, Księgarnia św. Jacka, Katowice 2003.

Kmiotek K., T. Piecuch, Zachowania organizacyjne. Teoria i przykłady, Difin, Warsaw 2012.

Koźmiński A.K., D. Jemielniak, Zarządzanie od podstaw, Wolters Kluwer business, Warsaw 2011.

Kupny J., Przedsiębiorstwo wspólnota osób pracujacych [in:] Katolicka Nauka Społeczna. Podstawowe zagadnienia z życia gospodarczego, eds. J. Kupny, S. Fel, Księgarnia św. Jacka, Katowice 2003.

Marek A., Capital, Resource or People? Contemporary Trends in Personnel Management, "Annales. Ethics in Economic Life" 2014, Vol. 17, No. 2.

Marek A., Zarządzanie przez kulturę organizacyjna jako sposób na rozwój potencjału pracowników [in:] Nowe tendencje w zarządzaniu, ed. M. Pawlak, Wydawnictwo KUL, Lublin 2010.

Perspektywy rozwoju partycypacji pracowniczej w Polsce w warunkach Unii Europejskiej, ed. S. Rudolf, Lodz University Press, Lodz 2007.

Pffefer J., The Human Equation: Building Profits by Putting People First, Harvard Business School Press, Boston 1998.

Pius XI, Quadragesimo anno, Jedność, Kielce 1946.

Pontifical Council of Justice and Peace, Vocation of the Business Leader: A Reflection, Vatican 2012.

Sekuła Z., Motywowanie do pracy. Teorie i instrumenty, PWE, Warsaw 2008.

Sobór Watykański II, Konstytucja duszpasterska o Kościele w świecie wspótczesnym Gaudium et spes, No. 67, Pallotinum, Poznan 2012.

Stankiewicz-Mróz A., Przywództwo wyzwaniem dla wspótczesnego kierownika [in:] Zarzadzanie zasobami ludzkimi dla menedżerów średniego szczebla, eds. E. Jędrych, Wolters Kluwer Polska, Cracow 2007.

Stocki R., P. Prokopowicz, G. Żmuda, Petna partycypacja w zarządzaniu. Tajemnica sukcesu największych eksperymentów menadżerskich świata, Wolters Kluwer Polska, Cracow 2008.

Storsletten V.M.L., O.D. Jakobsen, Development of Leadership Theory in the Perspective of Kierkegaard's Philosophy, "Journal of Business Ethics" 2014, No. 128, pp. 337-349; doi: 10.1007/s10551-014-2106-y. 
Świątkowski M., Zarządzanie przez kulturę organizacji [in:] Wymiary przywództwa w organizacji XXI wieku, ed. W. Bańka, Wydawnictwo naukowe NOVUM, Plock 2004.

Wajda A., Osobowość przywódcy, style przewodzenia [in:] Wymiary przywództwa w organizacji XXI wieku, ed. W. Bańka, Wydawnictwo naukowe NOVUM, Plock 2004.

Wymiary przywództwa w organizacji XXI wieku, ed. W. Bańka, Wydawnictwo naukowe NOVUM, Plock 2004.

Zarządzanie zasobami ludzkimi dla menedżerów średniego szczebla, ed. E. Jędrych, Wolters Kluwer Polska, Cracow 2007. 